\title{
Preliminary pharmacognostic and phytochemical study on Argyreia cymosa root
}

\begin{abstract}
Background: Ethnomedicinally, the plant Argyreia cymosa (Convolvulaceae) is certainly utilized for numerous disorders in the traditional system; notably it is employed against sexually transmitted ailments, skin problems, diabetes, rheumatism, cough, and quinsy. The primary obstacle accomplished in the standardization of natural medication may be the deficit of appropriate identity of plant origin. Consequently there may be need to set up quality control variables by using pharmacognostic and phytochemical analysis, that may assure the purity, safety, and efficiency of therapeutic herb A. cymosa.
\end{abstract}

Aim: To evaluate pharmacognostic features including macroscopic, microscopic and physicochemical parameters of the root of $A$. cymosa.

Methods: Micro and Macroscopic features of fresh and dried root samples were explored. Physicochemical variables was done by implementing WHO urged variables, preliminary phytochemical and fluorescent evaluation of root sample had been performed intended for correct recognition and standardization of root of A. cymosa.

Results: The colour, shape, size, odor, and surface features had been observed from the root and then powder root material of A. cymosa. Light electron microscope i.e. Olympus CX-21i trinocular Microscope images of cross section of root and powdered root revealed that the existence of cork cells, Xylem fibers with tapered ends, lignified xylem vessels, phloem fibers, medullary rays, sclerides and parenchymatous cells. Phytochemical testing revealed the existence of flavonoids, alkaloids, tannins, phenols, steroids, acid compounds, glycosides, amino acids, and proteins. Physicochemical parameters including moisture content, ash value, extractive value and fluorescent behavior of root powder had been identified. These variables are useful which will distinguish the powdered drug material.

Conclusion: The present studies useful in an attempt to augment the data with regards to its standardization, identity and performing additional exploration on Ayurveda approach to medicine.

Keywords: pharmacognostic, phytochemical, Argyreia cymosa, physicochemical, fluorescence studies
Volume 7 Issue 4 - 2018

\author{
Venkateswarlu G,' Ganapathy S \\ 'Department of Pharmacognosy and Phytochemistry,A. M. \\ Reddy Memorial College of Pharmacy, India \\ ${ }^{2}$ Department of Pharmacognosy and Phytochemistry, Gitam \\ University, India
}

Correspondence: Correspondence:Venkateswarlu G, Department of Pharmacognosy and Phytochemistry,A. M. Reddy Memorial College of Pharmacy, Narsaraopet - 522 60I,A. P, India, Email: gvr9885@gmail.com

Received: July 17, 2018 | Published: August 29, 2018

\section{Introduction}

Medicinal plants often taking part in an important part in traditional medications intended for treatment of various health conditions. Alternatively, a crucial hurdle which has impeded the promotion in the usage of alternate medications in the developed countries is no evidence of documentation and then deficit of rigorous quality control measures. Additionally there is a requirement of the records of all of the research work meted out on traditional medicines by using documents. On this issue, it is now necessary to help to make assurance about the standardization of the herb as well as parts to be utilised as a medication. Along the way of standardization, we are able to utilize different approaches and strategy to achieve the goal in a stepwise manner e.g. pharmacognostic and phytochemical analyses. These kinds of strategies and techniques are helpful on recognition and standardization of the plant material. Appropriate depiction and quality assurance of starting materials is a crucial stage to ensure a reproducible quality of herbal medication to aid us to justify its safety and effectiveness. For that reason, we now have accomplished pharmacognostic research of Argyreia cymosa (A. cymosa) belongs to family Convolvulaceae. ${ }^{1}$ This type of research is not going to help in authentication additionally, ensures reproducibility of herbal merchandise in marketing. ${ }^{2}$
In the current study, we are emphasizing our investigation on one of the commonly available plant in India i.e., A. cymosa, belongs to family Convolvulaceae. The family Convolvulaceae contains nearly 1650 predominantly exotic species. The genus Argyreia, with around 135 species, some of the important species include A. aggregate, $A$. cuneata, A. cymosa, A. daltoni, A. elliptica, A. fulgens, A. kleiniana, A. malabarica, A. nervosa, A. cymosa, A. setosa, A. strigosa and $A$. speciosa..$^{3-5} A$. cymosa is a stragglers on thickests; stem woody, terete, pubescent, leaves deltoid to cordiform, 6-8 X 4-6 cm, chartaceous, thinly pubescent on both sides, entire, acute or obtuse, base truncate or cordate; flowers pinkishin axillary, corymbose cymes; fruit globose, 1.7 X $1.4 \mathrm{~cm}$, glabrous; seeds 2,3 or 4 ovate to elliptic, black. ${ }^{6,7}$

A. cymosa is an ornamental, in addition to a medicinal plant. All parts of this plant are widely used as a folklore medicine for the treatment of various ailments by the Indian traditional healer. Its root is utilized to cure a various illness like sexually transmitted diseases viz., gonorrhea and syphilis, blood diseases, cracks and wounds. ${ }^{8-10}$ The leaf extracts of Clausena dendata and Argyreia cymosa is applied to the eyes of sheep and goat to cure cirneal opacity. ${ }^{11}$ The plant has been reported a few biological activities including Antibacterial ${ }^{9}$ 
and Antioxidant. ${ }^{12}$ Even though the drug has many uses, it's pharmacological and phytochemistry is very poorly explored..$^{13}$

Hence the current exploration have been accomplished to analyze the morphological, microscopical, physicochemical and phytochemical analysis along of root of $A$. cymosa together with the purpose of contributing to the establishment of monograph. ${ }^{14,15}$

\section{Material and methods}

\section{Collection and authentication of plant material}

The herbal material was purchased from Tirupati, Chittoor district of Andhra Pradesh, India within the month of June 2018 and authenticated by Dr. K. Madhava chetty, Taxonomist, Sri Venkateswara University Tirupati, India. Voucher specimen No. 1568 was placed at the herbarium for future reference. One part of the root is conserved in Formalin $(5 \mathrm{ml})$ : Acetic acid $(5 \mathrm{ml}): 70 \%$ Alcohol $(90 \mathrm{ml})$ blend pertaining to histological research as well as the remaining part was shade dried, powdered and then sieved by using 20 mesh and as well, retained within an air tight container for long term use. ${ }^{16}$

\section{Chemicals}

Every analytical grade chemical substances had been utilized for this research had been acquired from E. Merck, Germany. absolute alcohol, Phloroglucinol, acetic acid, chloral hydrate, $\mathrm{H}_{2} \mathrm{SO}_{4}, \mathrm{NaOH}$, $\mathrm{HNO}_{3}, \mathrm{FeCl}_{3}$, distilled water, Conc. $\mathrm{HCl}$ and chloroform.

\section{Pharmacognostic evaluation}

Organoleptic evaluation: Organoleptic evaluation of $A$. cymosa root have been executed with respect the colour, size, odor, shape, taste, surface and fracture according to WHO Quality Control methods of herbal medicine. ${ }^{17}$

\section{Microscopic evaluation}

Preparation of sections: The root bark was put into a test tube filled with sufficient water and was boiled for couple of minutes. The softened bark was transversally and longitudinally chopped into fine sections. Microscopic analyses have been made by preparing thin hand section of root by using sharp cutting edge of the blade, after that cleaned with chloral hydrate solution, stained with phloroglucinolhydrochloric acid (1:1) and affixed in glycerin. The type of microscope employed for the study of different characters was Olympus CX-21i trinocular Microscope, illumination halogen.

\section{Powdered microscopy}

The powder microscopy was carried out in accordance with the procedure described in Khandelwal ${ }^{18}$

\section{Preparation of extracts and preliminary phytochemical analysis}

The powder material have been extracted with different solvents depending to its polarity i.e., petroleum ether, ethyl acetate, chloroform, and methanol. 100g root powder was extracted with $500 \mathrm{ml}$ of the particular solvent by maceration at room temperature for 24 hours. After that, strained by using Whatman filter paper and then obtain the filtrate, concentrated with the roto-evaporator. Then, the extracts was confronted with preliminary phytochemical screening as mentioned in standard methods. ${ }^{18-20}$

\section{Physicochemical analysis}

Physicochemical parameters including ash value, moisture content and extractive values had been established based on the techniques described in WHO quality control methods for herbal materials. ${ }^{17,21,22}$

\section{Fluorescence analysis}

Various reagents were utilized to check the fluorescence activity. In this, $0.1 \mathrm{~g}$ of plant powder was blended with $1.5 \mathrm{ml}$ of respective reagent. The mixture was placed on the slide for a minute and observed under visible light, short ultra-violet light (254nm) and long ultraviolet light $(365 \mathrm{~nm}){ }^{15}$

\section{Results}

\section{Organoleptic evaluation}

Root powder was buff in color, no characteristic odor, and taste (Figure 1) (Table 1).

Table I Organoleptic characteristics of Argyreia cymosa root

\begin{tabular}{ll}
\hline Organoleptic characters & Observation \\
\hline Colour & Buff \\
Odour & Characteristic \\
Taste & No taste \\
Size & 30 to $35 \mathrm{~cm}$ \\
Texture & Rough \\
Fracture & Fibrous \\
\hline
\end{tabular}

Figure I Macroscopic characteristics of Argyreia cymosa root.

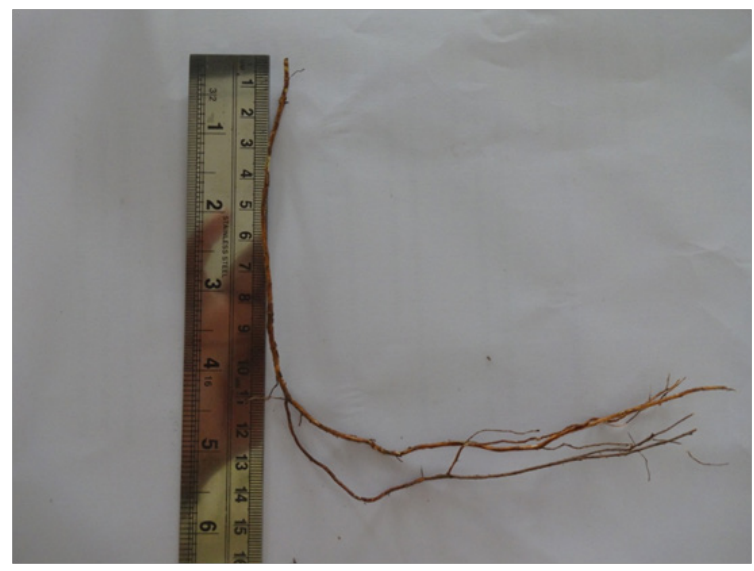

\section{Microscopical evaluation}

\section{Root}

Transverse section of root revealed the presence of cork, composed of about 6-7 tangentially elongated, thick walled cells. Beneath, there is a presence of stone cells, which are lignified in nature. Cortex was comprised of thin walled parenchymatous cells having very small intercellular spaces. The endodermis revealed the presence of phloem and xylem, which were very well developed. Xylem occupies more region than the phloem in endodermis. The phloem is present in between the medullary rays. The medullary rays are usually parenchymatous and they are uniseriate. Phloem revealed the presence of phloem fibers which are non-lignified in nature. Additionally, it revealed the presence of phloem parenchyma. The xylem occupies the whole central region and was also surrounded by uniseriate medullary rays. Xylem tissue comprises of spiral xylem vessels, xylem fibers, and xylem parenchyma as shown in Figure 2-6. 


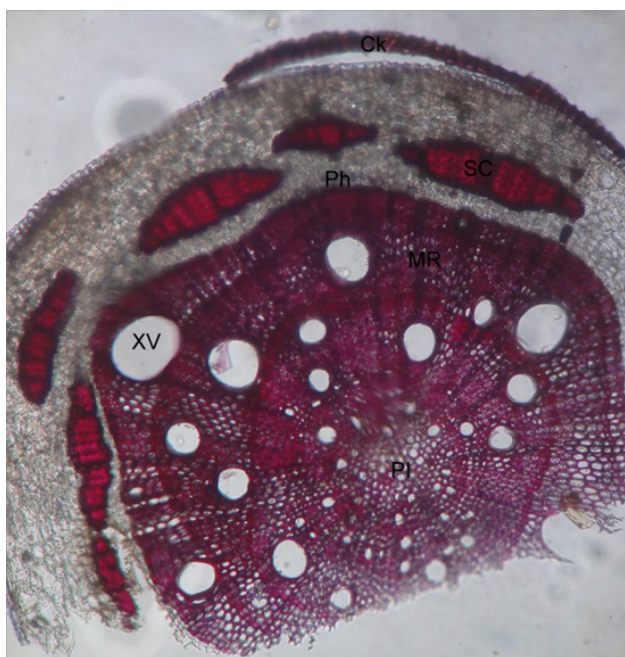

Figure 2 Transverse section of Argyreia cymosa root.

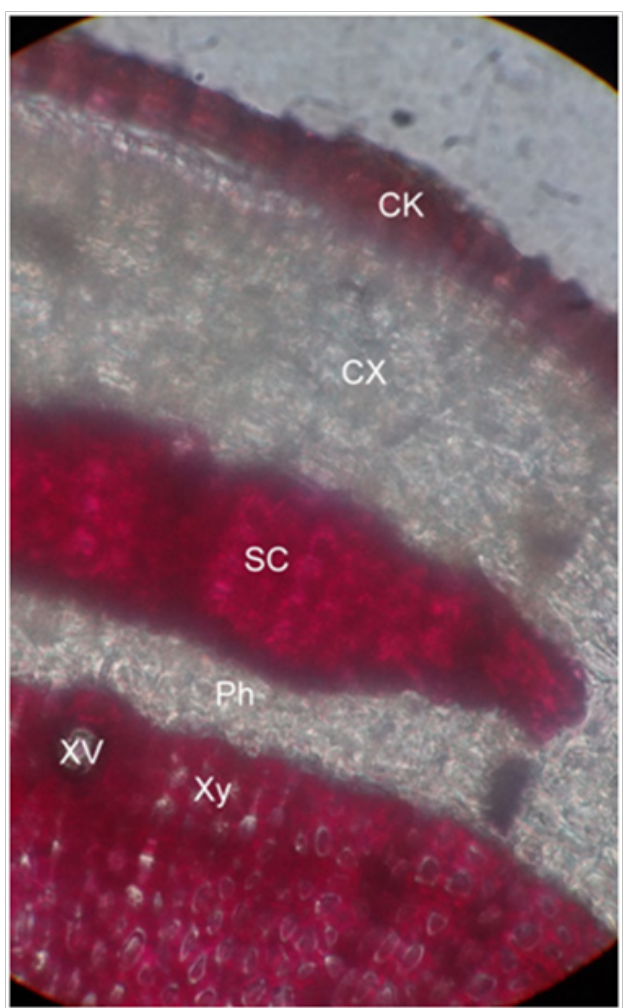

Figure 3 Transverse section of $A$. cymosa revealed the presence of cork, cortex, stone cells, phloem and xylem regions.

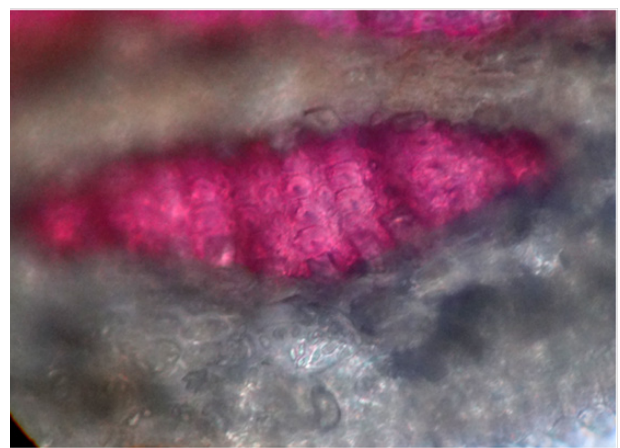

Figure 4 Magnification of stone cells at 40X.

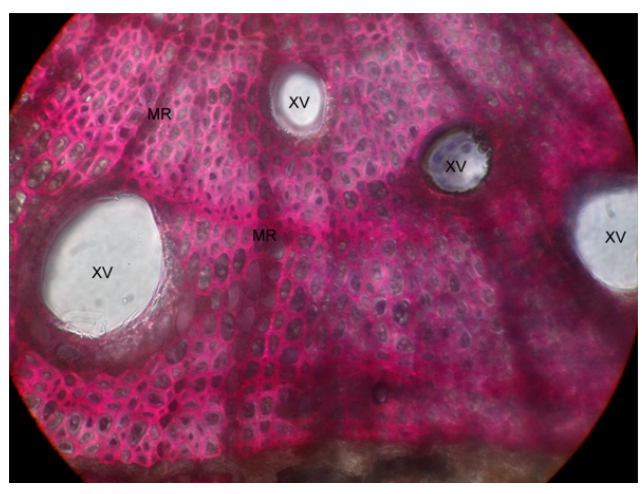

Figure 5 Transverse section of A. cymosa root showed xylem vessels and medullary rays.

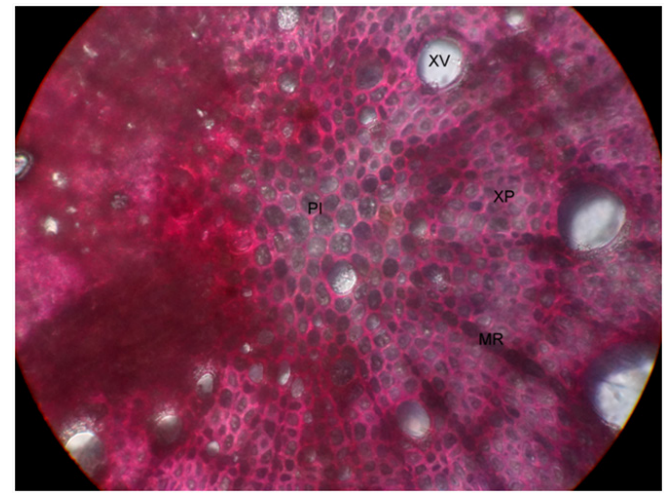

Figure 6 Central portion of A. cymosa root showed xylem vessels, xylem parenchya, medullary rays and pith.

\section{Powder microscopy}

The powdered root was brown in color, which revealed the presence of cork cells, Xylem fibers, Xylem vessels, Parenchyma cells, Phloem fibers, sclerides and medullary rays as showed in the Figure 7.

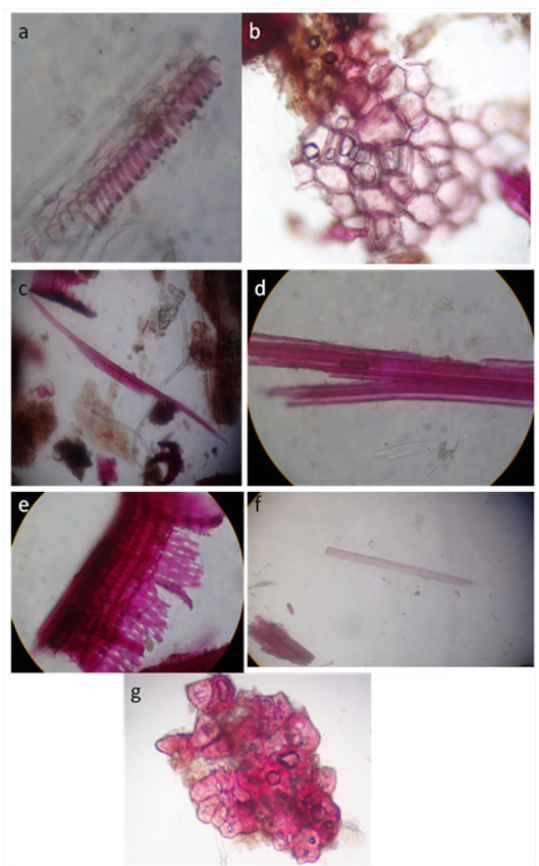

Figure 7 Powder Microscopy of the root of Argyreia cymosa. (A) Lignified xylem vessels, (B) Cork cells in surface view, (C) Xylem fiber with tapered ends, (D) Xylem fibers with non-tapered ends, (E) Medullary rays (F) Phloem fibers, (G) Stone cells.

Citation:Venkateswarlu G, Ganapathy S. Preliminary pharmacognostic and phytochemical study on Argyreia cymosa root.J Anal Pharm Res. $2018 ; 7(7): 494-498$. DOI: 10.15406/japlr.2018.07.00273 
Preliminary phytochemical analysis

The results of qualitative phytochemical analysis of crude powder of A. cymosa root was tabulated in Table 2 .

Table 2 Phytochemical analysis of various extracts of Argyreia cymosa root

\begin{tabular}{|c|c|c|c|c|c|}
\hline Phytoconstituents & Method & $\begin{array}{l}\text { Pet. Ether } \\
\text { extract }\end{array}$ & $\begin{array}{l}\text { Ethyl acetate } \\
\text { extract }\end{array}$ & Chloroform extract & Methanol extract \\
\hline \multirow[t]{3}{*}{ Flavonoids } & Shinoda Test & - & + & - & + \\
\hline & Zn. Hydrochloride test & - & + & - & + \\
\hline & Lead acetate Test & - & + & - & + \\
\hline Volatile oil & Stain test & - & - & - & - \\
\hline \multirow[t]{2}{*}{ Alkaloids } & Wagner Test & - & - & + & + \\
\hline & Hager's Test & - & - & + & + \\
\hline \multirow[t]{2}{*}{ Tannins \& phenols } & $\mathrm{FeCl}_{3}$ Test & - & + & - & + \\
\hline & Potassium dichromate test & - & - & - & + \\
\hline Saponins & Foaming Test & - & - & - & - \\
\hline Steroids & Salkowski test & + & - & + & + \\
\hline Fixed oils and fats & Spot test & + & - & - & - \\
\hline Carbohydrates & Molish test & - & - & - & + \\
\hline Acid compounds & Litmus test & - & - & - & + \\
\hline Glycoside & Keller-Killani Test & - & - & - & + \\
\hline Amino acids & Ninhydrin test & - & - & - & + \\
\hline Proteins & Biuret & - & - & - & + \\
\hline
\end{tabular}

"+"-- Present;"“-”-Absent

\section{Physicochemical parameters}

The results attained from various determinations of physicochemical analysis are tabulated in Table 3 .

Table 3 Physicochemical parameters of root powder of Argyreia cymosa

\begin{tabular}{ll}
\hline Parameters & Values $\% \mathrm{w} / \mathrm{w}$ \\
\hline Moisture content (Loss on drying) & $5.28 \pm 0.21$ \\
Total ash & $6.56 \pm 0.78$ \\
Acid insoluble ash & $2.45 \pm 0.12$ \\
Water soluble ash & $1.85 \pm 0.04$ \\
Petroleum ether soluble extractive value & $0.68 \pm 0.05$ \\
Chloroform soluble extractive value & $1.85 \pm 0.1$ \\
Ethyl acetate soluble extractive value & $3.23 \pm 0.12$ \\
Methanol soluble extractive value & $7.25 \pm 0.08$ \\
Water soluble extractive value & $10.52 \pm 0.15$ \\
\hline
\end{tabular}

\section{Fluorescence analysis}

Fluorescence analysis of root powder was performed out after treating with different solvents. Fluorescence was observed at 254 and $365 \mathrm{~nm}$ comparing its change of color in visible light. The observations were tabulated in Table 4 shows the variation in color.
Table 4 Fluorescence analysis of Argyreia cymosa root powder

\begin{tabular}{|c|c|c|c|}
\hline \multirow[t]{2}{*}{ Solvent used } & \multirow{2}{*}{$\begin{array}{l}\text { Visible } \\
\text { light }\end{array}$} & \multicolumn{2}{|l|}{ UV light } \\
\hline & & $\begin{array}{l}\text { At short } \\
(254 \mathrm{~nm})\end{array}$ & $\begin{array}{l}\text { At long } \\
(366 \mathrm{~nm})\end{array}$ \\
\hline Distilled water & Buff & Brown & Black \\
\hline $\begin{array}{l}\text { I N NaOH IN } \\
\text { Methanol }\end{array}$ & $\begin{array}{l}\text { Brownish } \\
\text { red }\end{array}$ & Brownish green & Black \\
\hline IN HCl & $\begin{array}{l}\text { Pale } \\
\text { Brown }\end{array}$ & Reddish brown & Brown \\
\hline $50 \% \mathrm{HNO}_{3}$ & Crimson & Brown & Green \\
\hline $\mathrm{FeCl}_{3}$ & $\begin{array}{l}\text { Brownish } \\
\text { blue }\end{array}$ & Black & $\begin{array}{l}\text { No } \\
\text { fluorescence }\end{array}$ \\
\hline $\mathrm{CHCl}_{3}$ & Buff & Dark brown & Black \\
\hline Picric acid & $\begin{array}{l}\text { Brownish } \\
\text { yellow }\end{array}$ & Yellowish green & $\begin{array}{l}\text { No } \\
\text { fluorescence }\end{array}$ \\
\hline
\end{tabular}

\section{Discussion}

Indian systems of medicine utilize majority of the crude drugs which are of plant origin. It is important that standards need to be set down to control and check the identity of the plant and confirm its quality before use. Hence a detailed pharmacognostic assessment is an extremely an important prerequisite. In accordance with World Health Organization (WHO), the organoleptic and histological description of a medicinal plant could be the first step towards establishing its identity and purity and should be performed before to any tests tend to be undertaken. ${ }^{23}$ 
A. cymosa, extensively utilized in conventional medicines has tremendous therapeutical potential due to its various biological activities. The prominent diagnostic characteristics of root showed the presence of cork cells, Xylem fibers, Phloem fibers and medullary rays. These characters can be utilized for standardization of drugs as well as used for preparation of plant monograph and also reduces the possibilities of adulteration when the drug is available in the powdered form. Studies of physicochemical parameters can serve as an important source to judge the purity and quality of crude drugs. Ash values are utilized to establish the quality and purity of the crude drug. It implies the existence of various impurities like carbonate, oxalate, and silicate. The water soluble ash is water soluble part of total ash, employed to calculate the amount of inorganic substances found in the drugs. The acid insoluble ash comprises mostly silica and indicates contamination with earthy matter. The moisture content of drugs might be at a minimum level in order to suppress the growth of microorganisms like bacteria, yeast or fungi during storage. The extractive values are helpful to judge the chemical constituents present in the crude drug and also assist in the evaluation of particular constituents soluble in a specific solvent. Acid insoluble ash measures the amount of silica present, especially sand. Water soluble ash is water soluble part of total ash. ${ }^{24-26}$ The phytochemical analysis of different solvent extracts viz., chloroform, methanol, and water were analyzed and it indicates the presence of tannins, flavonoids, steroids, glycosides, volatile oil, amino acids, proteins, and alkaloids.

Since there is no pharmacognostic work on documented of this traditionally significant valued drug, the current work had been taken up with a view to lay down standards that could be helpful to establish the authentication of this medicinally important plant. Macro and micro morphological standards discussed here can be considered as identifying parameters to authenticate the drug.

\section{Conclusion}

Standardization of herbal drugs is very much crucial because they are produced from heterogeneous sources which could result in variations. These kinds of variations can cause spurious results in various pharmacological and phytochemical studies. Argyreia cymosa the whole plant was recognized for many therapeutical properties, therefore, the current study might be beneficial to supplement the information in respective to its identification, authentication, and standardization; no such information is available for the same till date.

\section{Acknowledgments}

None.

\section{Conflict of interest}

The author declares no conflict of interest.

\section{References}

1. Akbar S, Hanif U, Ali J, et al. Pharmacognostic studies of stem, roots and leaves of Malva parviflora L. Asian Pac J Trop Biomed. 2014;4(5):410415.

2. Amponsah IK, Mensah AY, Otoo A, et al. Pharmacognostic standardisation of Hilleria latifolia (Lam.) H. Walt.(Phytolaccaceae). Asian Pac J Trop Biomed. 2014;4(12):941-946.

3. Traiperm P, Staples GW. A new endemic Thai species of Argyreia (Convolvulaceae). Phytotaxa. 2014;164(4):281-285.

4. Chetty KM, Sivaji K, Rao KT. Flowering Plants of Chittoor District. Tirupati, India: Student Offset Printers; 2008.

5. Ambasta S. The useful plants of India. New Delhi: CSIR; 1986:918.
6. Pullaiah T. Flora of Guntur District, Andhra Pradesh, India. New Delhi: Daya Books; 2000:417.

7. Matthew KM. An excursion flora of central Tamilnadu, India. USA: CRC Press; 1995.

8. Bharathajothi P, Jegatheesan M. Ethno dermatological plants used by the Paliyar tribals of western Ghats, Puliangudi, Tirunelveli district, Tamil Nadu, India. International Journal of Current Res. 2017;9(7):5343653438.

9. Packialakshmi N, Beevi HF. Antibacterial screening on leaves of Argyreia cymosa roxb. against pathogenic bacteria isolated from infected pateints samples wound, sputum and stool. International Journal of Applied Sciences and Biotechnology. 2014;2(3):279-282.

10. Bokhad MN, Rothe S. An overview of medicinally important lianas from dry deciduous forest of west Vidarbha region (MS) India. Bioscience discovery. 2015;6(2):117-120.

11. Ganesan S, Chandhirasekaran M, Selvaraj A. Ethnoveterinary healthcare practices in southern districts of Tamil Nadu. CSIR. 2008:347-354.

12. Badami S, Vaijanathappa J, Bhojraj S. In vitro antioxidant activity of Argyreia cymosa bark extracts. Fitoterapia. 2008;79(4):287-289.

13. Jhade D, Ahirwar D, Jain R, et al. Pharmacognostic standardization, physico-and phytochemical evaluation of Amaranthus spinosus linn. Root. $J$ Young Pharm. 2011;3(3):221-225.

14. Ghorpade P, Siddiqui A, Patil MJ, et al. Pharmacognostic and phytochemical evaluation of Celosia argentea. Pharmacognosy Journal. 2012;4(33):7-15.

15. Kataria S, Rao SK, Bhandari A, et al. Pharmacognostical standardization of Corchorus depressus (L.) Stocks (Tiliaceae)-A promising ethnomedicinal plant. Indian Journal of Traditional Knowledge. 2013;12(3):489-497.

16. Choudhary N, Siddiqui M, Khatoon S. Pharmacognostic evaluation of Tinospora cordifolia (Willd.) Miers and identification of biomarkers. Indian Journal of Traditional Knowledge. 2014;13(3):543-550.

17. World Health O. Quality control methods for herbal materials Geneva: World Health Organization; 2011.

18. Khandelwal KR. Practical pharmacognosy: techniques and experiments. Maharashtra: Niral Prakashan; 2008.

19. Harborne JB. Phytochemical methods; a guide to modern techniques of plant analysis. London: Chapman \& Hall; 1973:302.

20. Bladt S. Plant drug analysis: a thin layer chromatography atlas. Germany: Springer-Verlag Berlin Heidelberg; 1996:384.

21. Alam F, Najum us Saqib Q. Pharmacognostic standardization and preliminary phytochemical studies of Gaultheria trichophylla. Pharm Biol. 2015;53(12):1711-1718.

22. Singh P, Khosa RL, Mishra G, et al. Pharmacognostical evaluation of aerial parts of Graptophyllum pictum (L.) Griff. (Syn: Justicia picta Linn.): A well-known folklore medicinal plant. Anc Sci Life. 2015;34(4):223-229.

23. Rakholiya K, Chanda S. Pharmacognostic, physicochemical and phytochemical investigation of Mangifera indica L. var. Kesar leaf. Asian Pac J Trop Biomed. 2012;2(2):S680-684.

24. Dave R, Nagani K, Chanda S. Pharmacognostic studies and physicochemical properties of the Polyalthia longifolia var. pendula leaf. Pharmacognosy Journal. 2010;2(13):572-576.

25. Vaghasiya Y, Nair R, Chanda S. Antibacterial and preliminary phytochemical and physico-chemical analysis of Eucalyptus citriodora Hk leaf. Nat Prod Res. 2008;22(9):754-762.

26. Prasanth D, Rao AS, Yejella RP. Assessment of pharmacognostic, phytochemical and physicochemical standards of Aralia racemosa (L.) root. Ind J Phem Edu Res. 2016;50(3):S225-S230. 